UDC 81'366.5:371.81=161.2

DOI https://doi.org/10.32841/2409-1154.2021.48-4.7

\author{
Bolotnikova A. P., \\ Candidate of Philological Sciences, Associate Professor, \\ Associate Professor at the General Linguistics and Foreign Languages Department \\ National University "Yuri Kondratyuk Poltava Polytechnic"
}

Moskalenko M. V.,
Lecturer at General Linguistics and Foreign Languages Department,
National University "Yuri Kondratyuk Poltava Polytechnic"

Holovachova Ye. O.,

Student at the Faculty of Humanities

National University "Yuri Kondratyuk Poltava Polytechnic"

\title{
VOCATIVE GRAMMAR INDICATORS IN UKRAINIAN COMMUNICATIVE CULTURE
}

Summary. The article investigates the national and cultural specifics of vocatives in the Ukrainian communicative culture, analyzes the grammatical indicators of vocatives in the Ukrainian language etiquette, and establishes their functional potential. The focus is on the theoretical aspects of the politeness and language etiquette study in Ukrainian linguistic culture. The role of the politeness category in the process of communication and its linguopragmatic features have been revealed. It has been proved that the system of language units demonstrating relations between people is represented in the Ukrainian language at the grammatical level. The authors emphasize that the differential feature of Ukrainian language etiquette is manifested in the fact that in the Ukrainian language vocatives are characterized by special specificity and expressiveness due to the fact that in the singular they are mostly expressed in the form of the noun. A peculiar form of Ukrainian politeness is described as "a set of honor". In addition, it is emphasized that the language units use depends on the cultural characteristics and its level of development. It has been proved that politeness does not exist regardless of time and space; it is set by a particular society at a certain historical stage of its development. The category of politeness has a pronounced national and cultural specificity, knowledge of which is an important component of other cultural and linguistic traditions communicative competence bearers, a necessary condition for successful intercultural communication. In conclusion, it has been noted that Ukrainian politeness is a system of the Ukrainian ethnos speech behavior characteristic rules, and it is also implemented in a set of clichéd formulas. Politeness for Ukrainians is the absence of encroachment on the freedom of the addressee; it is based on strategies, the main ones being to show attention and respect to the communicative partner, to create an atmosphere of politeness, to avoid direct requests and to use indirect speech acts. It is important to study the formal grammatical indicators of politeness, to distinguish and analyze grammatical categories, to clarify their meaning and rules of use, to clarify the general grammatical system of politeness in the Ukrainian language.

Key words: politeness category, language etiquette, grammatical indicators, politeness formulas, treatment.

Formulation of the problem. In modern dynamic world, contacts of people speaking in different languages and being representatives of different cultures have been becoming commonplace. The focus of many sciences is an increased interest in intercultural communication, in particular in speech etiquette, namely: how to enter into a communicative act properly, be able to support and complete it verbally and nonverbally. According to etiquette rules, which are one of the forms of interaction between people, can differ both in small social groups and in national cultures, knowledge of these rules is very important for mutual understanding in communication of individuals who were raised in different cultures [1, p. 269]. Ignorance or inadequate reproduction of speech and non-speech behavior norms creates difficulties in communication between representatives of different linguistic and cultural communities and can cause various communicative deviations [2, p. 251].

In general, politeness plays an important role in organizing and optimizing the communication process, which is usually presented through language stereotypes (politeness formulas, pragmatic clichés). N. Balandina rightly notes: "Their linguistic status is indicated by such features as the standardity of the form with the predicted lexical structure and grammatical meaning, reproducibility in certain contexts, autosemanticity and the ability to enter into systemic syntagmatic and paradigmatic relations" [1, p. 297]. They, firstly, provide a comfortable atmosphere of speech interaction, secondly, structure the dialogue, creating the conditions for a dialogical perspective, and thirdly, regulate the completeness and transmission of information through communication channels. The category of politeness has recently become more and more of interest to representatives of various scientific fields. The system of language units that demonstrate relationships between people is represented in the Ukrainian language at all levels, and distinguishes grammatical, lexical and stylistic aspects of politeness. One of the most important and controversial issues is the grammatical nature of politeness, as the combination of speech etiquette into dialogic unity, their morphological composition and structure, the study of grammatical categories - these and other issues have not yet been resolved and are at the heart of linguistics.

An overview of the latest sources of research and publications. Grammatical indicators in Japanese were studied by V. Alpatov, S. Neverov, in Czech - N. Balandina, in Polish - M. Martsyanyk, K. Ozhug, in English - O. Spalanchuk and others. In the Ukrainian language, this issue is poorly developed. It is worth 
noting the dissertation research of $\mathrm{A}$. Bolotnikova "Grammatical indicators of politeness expression in the Ukrainian language" [3], aspectually this problem was researched by M. Bilous, S. Bohdan, O. Matsko, J. Radevych-Vynnytsky, M. Stelmakhovych, Ye. Chak and others.

Presentation of the main material and substantiation of research results. Considering the above, the representation of the category of politeness (hereinafter $\mathrm{CP}$ ) in the Ukrainian language is of particular interest, as it considers not complitely the possibility of expressing the social relations between communicators in the language by grammar, and if it is indicated, in fragments. Therefore, there is a need for a systematic study of grammatical means of CP expression in the Ukrainian language, which is promising in terms of clarifying the universal idioethnic aspects of conventional language communication.

The purpose of our research is to analyze the grammatical vocative indicators and describe their functional potential. Ukrainian speech etiquette, presented in the system of linguistic signs, symbols, verbal formulas and non-verbal means, forms a matrix, serves in various communication situations and is one of the codes that reveals the originality of the national-linguistic picture of the world. The verbal behavior of the people is in close connection with its culture, ethnopsychological features, traditions. In Ukrainian speech, along with the three-term formula "last name, first name and patronymic", names and appeals are intensively revived according to the model "master (lady/panna) + first name or/and last name" to analyze the grammatical vocative indicators and to describe their functional potential.

The theoretical and methodological principles developed at the present time enable to formulate and solve the urgent problem of studying the expression of CP in the situation of address. A. Bolotnikova convincingly emphasizes: "vocative correlates with the ability to "manage" the communicative process, which characterizes its use as a pragmatic strategy of influencing the intellectual, volitional and emotional spheres of the addressee, which is to reduce distance. The pragmatic strategy of using the exclamatory case is performed in the cognitive planning of the speaker's behavior aimed at the person of the addressee through the designation of his social role and the representation of the relationship between the interactants" [3, p. 68].

Ukrainian language etiquette, embodied in a system of language signs, symbols, verbal formulas and nonverbal means, forms a matrix that serves in various communication situations and is one of the codes that reveals the originality of the national-linguistic picture of the world. The language behavior of the people is closely connected with its culture, ethnopsychological features, and traditions. In the Ukrainian language, along with the three-membered formula "surname, name and patronymic", naming and addressing according to the model "Pan (Pani/Panna) + name and/or surname" is intensively renewed. Ya. Radevych-Vynnytskyi notes that in formal relations the model "Pan (Pani) + name-index" is further widely used [4, p. 118], for example: Pan redaktor (Pan editor), Pani likarka (Pani doctor); Pan likar (Pan doctor), Pan professor (Pan professor), Pani teacher (Pani teacher) and others. These models are increasingly displacing patronymics in Ukrainian speech etiquette, especially in the Right-Bank Ukraine. Addressing Pan, which is a word-regulation, indicating respect for the addressee (third party), requires the use of adjectives (name or surname, words-indexes), depending on the communication situation (formal-informal sphere; social status; age and other). Thus, in addressing the "lower" to the "higher" by social status, age, it is appropriate to avoid models such as "Pan (Pani) + name and/or surname", instead of giving preference to the model "Pan (Pani) + title-index", for example: Pan redactor (pan editor), Pan dyrektor (Pan director), Pani dekanka (Pani Dean), Pani likarka (Pani Doctor), Pan ministr (Pan Minister), Pan president (Pan president), etc., and in a situation of "higher" to "lower "under the same conditions, the first model is optimal, although the second one is possible.

In formal communication, the use of first and last name is parallel to the model "Mr. (Mrs.) + name and/or surname" or "Mr. (Mrs.) + index name". For example, pupils, students, as a rule, use such formulas in the address to teachers.

It should be noted that the Ukrainian language etiquette is gradually reviving the form of addressing an unmarried woman or girlPanno: "Oh, panno Inno, panno Inno!" Similar forms are found in many Western European languages, for example, in Spanish (señora - señorita), in French - (madam - mademoiselle), in German (frau - frauline), in English - (Miss - Mrs.), although the last two are walking towards unification. If the model "pani+ name and/or surname" and "pani + name-index" occur more and more often, then the model "panno + name and/or surname" and "panno + name-index" has not yet acquired its distribution among carriers. It is gradually becoming part of Ukrainian speech etiquette as a full-fledged one. Actually, this is what life itself dictates. The people, without waiting for recommendations, are already returning to ancient traditions, including language and etiquette.

In order to emphasize the vocative of politeness, interactants often resort to words-intensifiers, among which: adjectives, possessive pronouns and nouns [3, p. 83]. In modern speech etiquette of Ukrainians, in the role of defining words with the root pan-, it is most used are adjectives "shanovnyi", "shanovna", "shanovni", which are consistent with nouns in gender, number, case. A. Bolotnikova notes that "in addition to showing respect, intensifiers can be used to manipulate a communicative partner" [3, p. 84].

It is worth noting that pani in the Ukrainian language refers to indeclinable words, for example, poznaiomyvsia z pani (and not with paneiu) Oksanoiu, spilkuvavsia z pani (and not with paneiu) Svitlanoiu, bachyv pani (and not with paniu) Yablunivsku and so on.

In the plural use the collective noun panove, for example: Shanovni panove! Velmyshanovni panove! or Shanovni pani ta panove! The plural of the word pani has an unstable accent: it can be used both pa'ni and pani'. The first name turned out to be phonetically homonymous with the singular form of the word pani, therefore, in some cases, in order to avoid mixing the singular and plural forms, the second name is used. Today, the normative nature of such use is unresolved and is in the field of clarifying its necessity in the Ukrainian language.

The use of the words-regulators pan, pani, panna is justified when strangers enter into a communicative act in a certain situation. So, if, for example, in transport it can be heard: man, don't lie on me, woman, don't lean on me, girl, don't fall on me, then such statements have a shade of gender difference, but pane, pani, and don't lean on me, panno, do not fall on me sounds more polite, since such an appeal indicates the fulfillment of the passenger's social role by the communicants.

The differential feature of the language etiquette of Ukrainians is manifested in the fact that in the Ukrainian language vocatives are characterized by special specificity and expressiveness due to 
the fact that in the singular they are mostly expressed in the form of the noun: Dobroho dnia, Semene Petrovychu! Vitaiu Vas, Dmytre Oleksandrovychu! Yak Vashe zdorovia, Olho Ostapivno? Yak spravy, Nino Oleksiivno? Do zustrichi, pani Halyno! Usoho naikrashchoho, pane Olezhe! and so on. As evidenced by the results of our observations and sociolinguistic studies, the population uses the vocative case every day more and more often than, say, it was in the last decades of the twentieth century. A. Bolotnikova, a researcher of the politeness category in the Ukrainian language, notes: "The vocative case is a means of representing the addressee: demonstration of respect and solidarity, parity, benevolence, sincerity, emotionality and intimacy" [3, p. 88].

A nationally peculiar form of Ukrainian politeness is "Vy" is used to refer to a stranger, older in age, the position of the interlocutor, in the official sphere. "Ty" demonstrates a close relationship, conveys respect. Comrades, colleagues, employees, friends, brothers and sisters, spouses communicate with each other through "Ty" [5, p. 10].

The respectful "Vy" is used not in all countries. In particular, Swedes and Poles consider it not entirely polite, and therefore, as a rule, avoid it [4, p. 38]. In Ukrainian linguistics, there is an opinion (Ya. Radevich-Vynnytsky, M. Stelmakhovich) that there is no transposition of personal planes: addressing the addressee (interlocutor) as the third party, which is typical for Polish or Swedish, but it is not typical for Ukrainian. But it seems that this statement is not entirely true, since the form of address in the third person is gradually spreading more and more. Perhaps, on Ukrainian soil, it is not often used, but it tends to be used in parallel along with the traditional formula - the second person singular. It can be compared: Would you like to rest? and Does the guest (Mr., Mrs., Miss) want to rest?

Speech practice shows that the use of linguistic units depends on the characteristics and level of the society culture development. "Vy", which is a hallmark of Ukrainian politeness, represents the relationship between people, the level of respect and politeness towards each other. It can be argued that it performs the so-called etiquette function. Observing the rules of speech etiquette, we "first confirm our good breeding, respect and attentiveness to the interlocutor, friendliness, friendship, affection, benevolence, delicacy, that is, features that have long been inherent in our people" [6, p. 22].

Politeness is a component of speech etiquette and culture in general; it does not exist regardless of time and space; it is given by a specific society at a certain historical stage of its development. CP has a strongly pronounced national and cultural specificity, knowledge of which is an important component of the communicative competence of other cultural and linguistic traditions bearers, a necessary condition for successful intercultural communication.

Conclusions. Ukrainian politeness is a system of rules of the Ukrainian ethnos speech behavior characteristic, which has its expression in linguistic means (vocabulary and grammar), and is also implemented in a set of clichéd formulas. Politeness for the Ukrainian is the absence of an encroachment on the addressee's freedom; it is based on strategies, the main of which are showing attention and respect for a person, creating an atmosphere of group identity, striving for agreement, avoiding direct requests and using indirect speech acts. Therefore, promising, in our opinion, is the study of formal indicators of grammatical means expressing politeness, highlighting grammatical categories, clarifying their meaning and rules of use, identifying in general the grammatical system of politeness vocatives in the modern Ukrainian language.

\section{References:}

1. Национально-культурная специфика речевого поведения / ред. : А.А. Леонтьев, Ю.А. Сорокин, Е.Ф. Тарасов. Москва : Наука, 1977. $352 \mathrm{c}$.

2. Баландіна Н.Ф. Функції і значення чеських прагматичних кліше в комунікативному контексті : монографія. Київ : АСМI, 2002. 332 c.

3. Болотнікова А.П. Граматичні індикатори вираження категорії ввічливості в українській мові : дис. ... канд. філол. наук : 10.02.01. Запоріжжя, 2018. 257 c.

4. Радевич-Винницький Я.К. Етикет і культура спілкування. Львів : Сполом, 2001. $223 \mathrm{c}$.

5. Стельмахович М.Г. Мовний етикет українців. Культура слова. Київ, 1981. Вип. 20. С. 6-12.

6. Білоус М.П. Мовленнсвий етикет українського народу. Мова $i$ духовність нації : тези доповідей науково-практичної конференції, м. Львів, 14-15 листопада 1989 р. Львів : ЛДУ ім. І. Франка, 1989. C. $98-99$.

Болотнікова А. П., Москаленко М. В., Головачова Є. О. Граматичні індикатори звертання В українській комунікативній культурі

Анотація. У статті досліджено національно-культурну специфіку звертання в українській комунікативній культурі, проаналізовано граматичні індикатори звертання в українському мовному етикеті, встановлено їх функційний потенціал. Зосереджено увагу на теоретичних аспектах дослідження ввічливості, мовного етикету в українській лінгвокультурі. Розкрито роль категорії ввічливості у процесі спілкування та її лінгвопрагматичні ознаки. Доведено, що система мовних одиниць, які демонструють стосунки між людьми, представлена в українській мові на граматичному рівні. Автори вважають, що диференційна ознака мовного етикету українців проявляється в тому, що в українській мові вокативи характеризуються особливою специфічністю та виразністю у зв'язку з тим, що в однині вони здебільшого виражаються формою кличного відмінка іменника. Описано своєрідну форму української ввічливості - «множину шани». Крім того, наголошено на тому, що вживання мовних одиниць залежить від особливостей і рівня розвитку культури суспільства. Доведено, що ввічливість не існує поза часом і простором - вона задається конкретним суспільством на визначеному історичному етапі його розвитку. Категорія ввічливості має яскраво виражену національно-культурну специфіку, знання якої $€$ важливим складником комунікативної компетенції носіїв інших культурно-мовних традицій, необхідною умовою успішної міжкультурної комунікації. У висновку зауважено, що українська ввічливість - це система характерних для українського етносу правил мовленнєвої поведінки, що реалізується в наборі клішованих формул. Ввічливість для українців - це відсутність зазіхання на свободу адресата; вона базується на стратегіях, основними 3-поміж яких $є$ демонстрування уваги й поваги до комунікативного партнера, створення атмосфери ввічливості, уникнення прямих прохань та використання непрямих мовленнєвих актів. Важливим є дослідження формальних граматичних показників вираження ввічливості, виокремлення й аналіз граматичних категорій, з'ясування їх значення та правил вживання, а також загалом граматичної системи ввічливості української мови.

Ключові слова: категорія ввічливості, мовний етикет, граматичні індикатори, формули ввічливості, звертання. 